\title{
Citalopram: Labelling with Carbon-11 and Evaluation in Rat as a Potential Radioligand for In Vivo PET Studies of 5-HT Re-uptake Sites
}

\author{
S. P. HUME', C. PASCALI ${ }^{1}$, V. W. PIKE ${ }^{1, *}$, D. R. TURTON ${ }^{1}$, \\ R. G. AHIER' ${ }^{1}$, R. MYERS', D. M. BATEMAN ${ }^{1}$, J. E. CREMER', \\ L. G. MANJIL ${ }^{1}$ and R. DOLAN ${ }^{2}$
}

${ }^{1}$ MRC Cyclotron Unit, Hammersmith Hospital, Ducane Road, London W12 OHS and ${ }^{2}$ Royal Free Hospital and School of Medicine, London NW3, England

(Received 12 March 1990; in revised form 28 June 1990)

\begin{abstract}
In vivo autoradiography of $\left[\mathrm{N}\right.$-methyl- $\left.{ }^{3} \mathrm{H}\right] \mathrm{citalopram}$ in rat brain shows a differential regional localization which correlates with the localization of 5-HT re-uptake binding sites defined in vitro. A comparison of the biodistribution of $\left[N\right.$-methyl $\left.-{ }^{3} \mathrm{H}\right]$ citalopram over $2 \mathrm{~h}$ after i.v. injection in (1) control rats (2) rats pre-dosed with either citalopram or paroxetine and (3) rats chemically-lesioned with $p$-chloroamphetamine provides an estimate of specific binding relative to total binding in vivo. The ratio of binding in certain regions (e.g. cingulate) to binding in a reference tissue (e,g, cerebellum) at $30-120 \mathrm{~min}$ post injection is c. 1.4. In view of these results a method was developed for labelling citalopram with carbon-11 $\left(t_{1 / 2}=20.3 \mathrm{~min}, \beta^{+}=99.8 \%\right)$ to provide a potential radioligand for studies using positron emission tomography. Thus, reaction of nca [ ${ }^{11} \mathrm{C}$ ]iodomethane, prepared from cyclotron-produced ["Clcarbon dioxide, with norcitalopram in ethanol containing 2,2,6,6-tetramethyl-piperidine for $5 \mathrm{~min}$ at $95^{\circ} \mathrm{C}$ gives crude $[N$-methyl-" $C$ citalopram in $60 \%$ radiochemical yield, decay-corrected. HPLC on silica gel provides radiochemically and chemically pure $\left[N\right.$ nethyl $\left.-^{\prime \prime} \mathrm{C}\right]$ citalopram, as assessed by TLC, HPLC and MS. This product (isolated radiochemical yield, $49 \%$ ) is easily formulated for i.v. injection. Up to $2 \mathrm{GBq}$ of formulated product with a specific activity of $c .15 \mathrm{GBq} / \mu \mathrm{mol}$ have been prepared within $40 \mathrm{~min}$ from the end of radionuclide production. The described radiosynthesis has also been applied to give the single biologically active (+)-enantiomer of $\left[N-\right.$ methyl $\left.{ }^{.1} \mathrm{C}\right]$ citalopram rather than the racemate. This product gives enhanced specific signal in the rat following i.v. injection, the ratio of uptake in regions of interest relative to cerebellum approaching 2 at $90 \mathrm{~min}$.
\end{abstract}

\section{Introduction}

Positron emission tomography (PET) (Phelps et al., 1975 ) is now widely established as a technique for investigating pathophysiology in living man. Much effort has been expended on developing PET for measurements in neurotransmitter systems whose dysfunction may play a role in the progress of poorly understood neuropsychiatric diseases (for reviews see Wagner, 1986; Sedvall et al., 1986; Frost, 1986). The dopaminergic system in relation to movement disorders and schizophrenia has received most attention, not least because markers for dopaminergic neurons and their associated receptors have been successfully labelled with suitable positronemitting radionuclides, mainly carbon- $11\left(t_{1 / 2}=20.3\right.$

*Author for correspondence. $\left.\min , \beta^{+}=99.8 \%\right)$ and fluorine-18 $\left(t_{1 / 2}=109.6 \mathrm{~min}\right.$, $\left.\beta^{+}=96.9 \%\right)$.

Much in vitro and post mortem evidence implicates a dysfunction in serotonergic neurotransmission in clinical depression. One hypothesis is that depression results from a deficiency in serotonin (5-HT) and hence that the well known tricyclic antidepressants counter this deficiency by specifically inhibiting the pre-synaptic re-uptake of 5-HT (reviewed by Fuller, 1987). More recent hypotheses implicate abnormal levels of either pre-synaptic 5-HT re-uptake sites or post-synaptic 5-HT 2 receptors (see Stahl and Palazidou, 1986).

Clearly, suitably radiolabelled markers of the serotonergic system might allow the aetiology of depression to be investigated using PET in living man. One approach is to develop a radioligand that is specific for the pre-synaptic 5-HT re-uptake site. 
Thus, tricyclic antidepressants [e.g. imipramine (Berger et al., 1979) and chlorimipramine (Mazière $e t$ al., 1978)] and also some recent non-tricyclic antidepressants [e.g. fluoxetine (Kilbourn et al., 1989) and sertraline (Lasne et al., 1989)] have been labelled with carbon-11 as potential radioligands. So far, none of these has been reported as efficacious for PET studies in man. Some, such as the labelled tricyclics and sertraline, are highly lipophilic and might be expected to give high levels of non-specific binding compared to specific re-uptake site binding in vivo. Recent studies confirm this behaviour for sertraline in rats (Hume et al., 1989). Candidate radioligands should therefore possess only enough lipophilicity to penetrate the blood-brain barrier. Also, to give a specific signal measurable with PET, a radioligand must generally have high selectivity and high affinity for the target site (e.g. a $K_{\mathrm{D}}, K_{\mathrm{I}}$ or $\mathrm{IC}_{50}$ value of less than $10 \mathrm{nM}$ in vitro) (see reviews by Sedvall et al., 1986; Frost, 1986).

The phthalane derivative, citalopram (I)*, inhibits the uptake of 5-HT into rat brain synaptosomes in vitro with an $\mathrm{IC}_{50}$ of $1.8 \mathrm{nM}$ (Hyttel, 1982). This inhibition is highly selective for the uptake of 5-HT as opposed to the uptake of dopamine (DA) or noradrenalin (NA) (Hyttel, 1982). Moreover, citalopram shows only low affinity for post synaptic neurotransmitter receptors (Hyttel, 1982). The in vitro labelling of rat brain with $\left[{ }^{3} \mathrm{H}\right]$ citalopram (presumed to be the racemate with label in the $N$-methyl position) has been described in detail by d'Amato et al. (1987). The tritium located in areas rich in serotonergic nerve terminals, particularly, raphe nucleus, locus coeruleus, superior colliculus, interpeduncular nucleus, medial septum and ventral caudate. From the kinetics and distribution of binding, the authors concluded that $\left[{ }^{3} \mathrm{H}\right]$ citalopram labels the high affinity imipramine site on the serotonergic uptake complex. Using the method of Hansch and Leo (1979), the lipophilicity of citalopram can be calculated as modest $\left(\log _{10} P=1.3\right)$. Though, in man, citalopram metabolizes mainly through $N$-demethylation (Overø, 1978), its biological half-life is long ( $33 \mathrm{~h}$ ) (Kragh-Sørensen et al., 1981) compared to the physical half-life of carbon-11. We therefore considered carbon-11 labelled citalopram to be a prospective radioligand for PET studies of 5-HT re-uptake sites.

This paper describes (1) the in vivo regional distribution of $\left[N\right.$-methyl $\left.-{ }^{3} \mathrm{H}\right]$ citalopram in rat brain, determined using routine autoradiographic and tissue counting techniques and (2) the successful preparation of $\left[N-\right.$ methyl $\left.{ }^{11} \mathrm{H}\right]$ citalopram at high specific

*1-[3-(Dimethylamino)propyl]-1-(4-fluorophenyl)-1,3-dihydro-5-isobenzofurancarbonitrile monobromide. In this paper, citalopram refers to the racemate unless otherwise indicated.

tThe animal studies were carried out by licensed invesgators in accordance with the British Council's Guidelines on the Use of Living Animals in Scientific Research, 2nd Edn. activity, as part of a preliminary assessment of its potential as a radioligand for PET.

\section{Methodst and Results}

(1) Biological Studies with $\left[N\right.$-methyl $-{ }^{3}$ HKCitalopram

\section{(a) Methods}

Male Sprague-Dawley rats (Harlan Olac Ltd, Bicester, U.K.) weighing $250-280 \mathrm{~g}$ were used in all studies. Before use, the rats were housed on a $12 \mathrm{~h}$ light-dark cycle with food and water ad libitum. The anaesthetic was isoflurane with nitrous oxide plus oxygen.

\section{HPLC}

Rats were decapitated, the brains rapidly removed and regions of interest dissected and weighed. The tissues were immediately homogenized in $20 \mathrm{vol}(\mathrm{w} / \mathrm{v})$ of ice-cold $0.1 \mathrm{M}$ perchloric acid (PCA) containing $0.1 \mu \mathrm{M}$ 3,4-dihydroxy-benzylamine (DHBA) as an internal standard and centrifuged at $\angle 2^{\circ} \mathrm{C}$ for $20 \mathrm{~min}$ at $15,000 \mathrm{~g}$ to precipitate protein. The supernatant was filtered (Millipore type HA, $0.45 \mu \mathrm{m}$ pore size) and $50 \mu \mathrm{L}$ injected directly onto the column (ESA 68-0100 catecholamine HR-80). The HPLC comprised an ESA 5100 Coulochem electrochemical detector with 5011 high sensitivity analytical cell, a 5021 conditioning cell and a SA 64010B solvent delivery system (Severn Analytical Ltd, U.K.). The mobile phase [0.1 $\mathrm{M} \mathrm{KH}_{2} \mathrm{PO}_{4}, 10 \% \mathrm{MeOH}, 0.1 \mathrm{mM}$ disodium EDTA and $2.5 \mathrm{mM} 1$-octane sulphonic acid sodium salt (Kodak, U.K.), pH 3.5] was filtered $(0.45 \mu \mathrm{m}$ pore size) and degassed before use. External standards were prepared as a mixture at $0.1 \mu \mathrm{M}$ in $0.1 \mathrm{M}$ PCA plus $0.1 \mu \mathrm{M}$ DHBA. All chemicals were HPLC grade. The catecholamines, 5-HT and acid metabolites were all measured in the same chromatographic run of approx. $25 \mathrm{~min}$. Peak area was measured using a MOP Videoplan (Kontron Ltd) and content expressed as $\mathrm{pmol} / \mathrm{mg}$ tissue. Control values were similar to those reported in the literature (Zaczek and Coyle, 1982; Slopsema et al., 1982).

\section{Microdialysis}

Rats were anaesthetized throughout the procedure. A 2 mm-microdialysis probe (CMA10; Carnegie Medicin, Sweden) was stereotaxically implanted in the fcrelimb area of the cortex using a Kopf stereotaxic frame. Coordinates from Bregma were: rostral $0.07 \mathrm{~mm}$, lateral $0.30 \mathrm{~mm}$, ventral $0.20 \mathrm{~mm}$ (Paxinos and Watson, 1986). The probe was perfused continuously with a modified Ringer solution $(\mathrm{KCl}, 4 \mathrm{mM}$; $\mathrm{CaCl}_{2} \cdot 2 \mathrm{H}_{2} \mathrm{O}, 2.3 \mathrm{mM} ; \mathrm{NaCl}, 147 \mathrm{mM}$ ) at $2 \mu \mathrm{L} / \mathrm{min}$ and the perfusate collected every $20 \mathrm{~min}$ using a CMA/100 micro-injection pump with CMA/140 microfraction collector (Carnegie Medicin, Sweden). Each 20 min sample ( $40 \mu \mathrm{L}$ plus $10 \mu \mathrm{L} 0.1 \mathrm{M}$ PCA, as antioxidant) was injected directly onto the HPLC column described earlier. 


\section{Autoradiography}

(i) In vitro. The method was similar to that described by d'Amato et al. (1987). Sagittal sections ( $10 \mu \mathrm{m}$-thick on gelatin-subbed glass slides) from a single control rat were pre-incubated for $15 \mathrm{~min}$ at room temperature in buffer $(50 \mathrm{mM}$, Tris; $120 \mathrm{mM}$, $\mathrm{NaCl} ; 5 \mathrm{mM}, \mathrm{KCl} ; \mathrm{pH} 7.4$ ) and for $60 \mathrm{~min}$ in $1 \mathrm{nM}$ $\left[N\right.$-methyl- $\left.{ }^{3} \mathrm{H}\right]$ citalopram with or without $1 \mu \mathrm{M}$ paroxetine hydrochloride (Beecham) as displacer. After incubation, the sections were washed twice with buffer at $4^{\circ} \mathrm{C}$ for $10 \mathrm{~min}$, rinsed twice with deionized water at $4^{\circ} \mathrm{C}$ and left to dry at room temperature.

(ii) In vivo. An awake, restrained rat was injected intravenously with a bolus of $[N$-methyl${ }^{3} \mathrm{H}$ ]citalopram $(3.7 \mathrm{MBq}$ or $100 \mu \mathrm{Ci}$ in $300 \mu \mathrm{L}$ physiological saline). At $60 \mathrm{~min}$ after injection the rat was killed with Expiral (Ceva Ltd, U.K.). The brain was removed, frozen in isopentane at -35 to $-40^{\circ} \mathrm{C}$ and embedded in Tissue-Tek O.C.T. compound. After equilibration at $-14^{\circ} \mathrm{C}$, serial $20 \mu \mathrm{m}$ coronal cryostat sections were cut (Bright Instruments Co. Ltd, U.K.), thaw-mounted onto glass slides and dried on a hot plate.

For both in vitro and in vivo autoradiography, the sections and standards (precalibrated $\left[{ }^{3} \mathrm{H}\right]$-microscales, Amersham International plc, U.K.) were apposed to ${ }^{3} \mathrm{H}-$ Hyperfilm (Amersham International plc, U.K.). The films were processed using Agfa G 150 developer. Autoradiograms were quantified as described in the figure legends, giving pmol/g tissue for the in vitro sections and uptake units for the in vivo sections.

\section{Brain distribution in vivo}

At 2-3 h prior to radioligand injection, a tail artery and vein were catheterized using polythene tubing (i.d. $0.58 \mathrm{~mm}$, o.d. $0.96 \mathrm{~mm}$; Portex Ltd, U.K.). After recovery from anaesthesia, the rats were kept lightly restrained in a modified Bollman cage (Waynforth, 1980).

For injection of $\left[\mathrm{N}-\right.$ methyl $\left.-{ }^{3} \mathrm{H}\right]$ citalopram, the stock was diluted 30 times with physiological saline and then $250 \mu \mathrm{L}$ given via the tail vein (c. $300 \mathrm{kBq}$ or $8 \mu \mathrm{Ci}$ per rat). At designated times after injection, samples of arterial blood (c. $200 \mu \mathrm{L}$ ) were withdrawn and aliquots of blood and plasma taken for counting. The rats were killed by i.v. injection of Expiral at graded times ranging between 5 and $120 \mathrm{~min}$ after injection of radioligand. The brains were rapidly removed and regions of interest dissected and weighed. The dissection used five 3-mm coronal slices of the cerebral hemispheres, as described by Palkovits and Brownstein (1988) with the reference cut immediately caudal to the inferior colliculi (P $9000 \mu \mathrm{m})$. The samples were solubilized with Soluene-350 (Packard, Groningen, The Netherlands) and counted using a Beckman LS 6800 with Hionic-Fluor, acidified with glacial acetic acid (1\%), as the scintillant (Packard).
The radioactive content was normalized and expressed in units of "uptake", defined as:

$$
\begin{aligned}
& \begin{array}{c}
\text { radioactivity }(\mathrm{Bq}) / \text { wet weight of tissue }(\mathrm{g}) \\
\text { or blood volume }(\mathrm{mL})
\end{array} \\
& \begin{array}{c}
\text { total injected radioactivity }(\mathrm{Bq}) / \\
\text { body weight }(\mathrm{g})
\end{array}
\end{aligned}
$$

\section{(b) Results}

\section{Microdialysis}

Intracerebral dialysis in combination with HPLC and electrochemical detection (Ungerstedt and Hallstrom, 1987) was used to assay extracellular levels of $5 \mathrm{HT}, \mathrm{NA}, \mathrm{DA}, 3$,4-dihydroxy-phenylacetic acid (DOPAC), homovanillic acid (HVA) and 5-hydroxyindole-3-acetic acid (5-HIAA) following an i.v. bolus injection of saline or citalopram hydrobromide at a dose of $5 \mathrm{mg} / \mathrm{kg}$.

Immediately after probe implantation, levels of 5-HT in the dialysate were high, possibly associated with release of 5-HT from platelets during blood clotting (Kalen et al,, 1988), but then sharply declined. The first sample was therefore discarded. Thereafter, output was expressed as pmol $/ 40 \mu \mathrm{L}$ sample, without correction for probe recovery. Since inter-animal variation was greater than baseline variation, changes in output following drug administration are expressed as a fraction of the last baseline value prior to treatment in each individual rat. Figure 1 illustrates DA, NA and 5-HT contents of consecutive 20 min samples of dialysate from cortex, relative to baseline levels in the fourth sample after implantation of the probe. Of the 5 rats that received the drug, none showed a significant change in DA content compared with those receiving saline. One rat showed a transient, delayed increase in NA content but all rats showed an immediate increase in 5-HT content, ranging between 2-6 times base levels, with some recovery over the next hour. The concentrations of the neurotransmitter metabolites, DOPAC, HVA and 5-HIAA, were not significantly altered by drug administration over the time of the experiment (data not presented).

\section{Autoradiography}

Figure 2 illustrates the specific binding of $[N$ methyl $\cdot{ }^{3} \mathrm{H}$ ]citalopram obtained in vitro, using a $1 \mathrm{~h}$ incubation at room temperature. (The binding was eliminated by addition of $1 \mu \mathrm{M}$ paroxetine to the incubation medium.) Quantitation of density in selected regions of interest from this and a further 7 sagittal sections (lateral -0.10 to $4.20 \mathrm{~mm}$, Paxinos and Watson, 1986) are presented in Table 1, together with values for mean binding in larger, more heterogeneous areas equivalent to those dissected in the assessment of the distribution of label in vivo. Representative in vivo autoradiograms from coronal sections taken $1 \mathrm{~h}$ after an i.v. injection of 

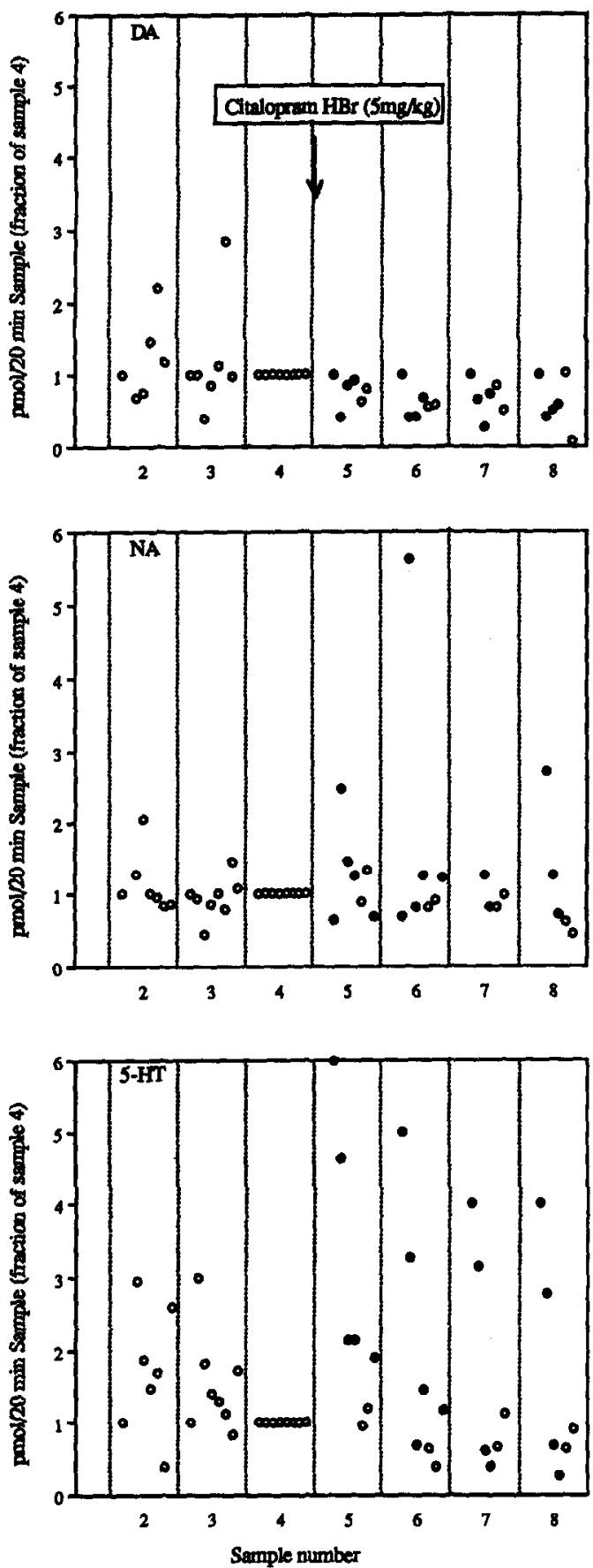

Fig. 1. Neurotransmitter levels in perfusate collected from a $2 \mathrm{~mm}$ probe stereotaxically implanted in the forelimb area of the cortex. Samples were collected over 20 min periods at a perfusion rate of $2 \mu \mathrm{L} / \mathrm{min}$. An i.v. injection of citalopram $\mathrm{HBr}$ (solid symbols) or an equivalent volume of saline (open symbols) was given at the end of the fourth sample. Mean values $( \pm S D)$ of the fourth sample were: $D A, 0.075 \pm 0.050$; $\mathrm{NA}, 0.052 \pm 0.030 ; 5-\mathrm{HT}, 0.088 \pm 0.059 \mathrm{pmol} / 20 \mathrm{~min}$. Data are from 8 rats, anaesthetized throughout the procedure. Each rat can be followed by its lateral position within the bin.

$\left[N\right.$-methyl $\left.-{ }^{3} \mathrm{H}\right]$ citalopram are presented in Fig. 3. Quantitation of uptake has been limited to areas corresponding to those regions which were handdissected (Table 2).
Table 1. Regional distribution of $\left[N-\right.$ methyl $\left.-{ }^{3} \mathrm{H}\right]$ citalopram binding

\begin{tabular}{lcc} 
in vitro \\
\hline $\begin{array}{c}\text { Specific tritium bindingt } \\
\text { (pmol/g tissue) }\end{array}$ & $\begin{array}{c}\text { ROI: } \\
\text { cerebellum }\end{array}$
\end{tabular}

\begin{tabular}{|c|c|c|}
\hline Region* & (pmol/g tissue) & cerebellum \\
\hline $\begin{array}{l}\text { Frontoparietal cortex } \\
\text { Entorhinal cortex } \\
\text { Olfactory tubercles } \\
\text { Islands of calleja } \\
\text { Globus pallidus } \\
\text { Basolateral amygdaloid n. } \\
\text { Posterior amygdaloid n. } \\
\text { Central amygdaloid n. } \\
\text { Laterodorsal thalamic } \mathrm{n} . \\
\text { Medial forebrain bundle } \\
\text { Dorsal dentate gyrus } \\
\text { Ventral dentate gyrus } \\
\text { Dorsal geniculate n. } \\
\text { Ventral geniculate n. } \\
\text { Medial geniculate n. } \\
\text { Superior colliculus, } \\
\text { superficial layer } \\
\text { lnferior colliculus } \\
\text { Substantia nigra } \\
\text { Facial nucleus } \\
\text { Corpus callosum }\end{array}$ & $\begin{array}{c}20.2 \pm 0.7 \\
7.9 \\
39.1 \\
56.1 \\
30.9 \pm 3.9 \\
33.6 \pm 3.0 \\
36.9 \\
43.3 \\
24.3 \\
55.9 \pm 3.9 \\
25.6 \\
16.9 \\
21.7 \\
38.3 \\
40.0 \\
\\
67.4 \pm 8.7 \\
26.2 \\
63.0 \\
44.8 \\
0.7 \pm 0.1\end{array}$ & \\
\hline $\begin{array}{l}\text { Frontoparietal cortex } \\
\text { Caudate putamen } \\
\text { Thalamus } \\
\text { Hippocampus } \\
\text { Medulla } \\
\text { Cerebellum }\end{array}$ & $\begin{array}{r}20.2 \pm 0.7 \\
24.3 \pm 1.6 \\
23.6 \pm 1.2 \\
13.1 \pm 0.4 \\
22.2 \pm 0.4 \\
2.4 \pm 0.1\end{array}$ & $\begin{array}{r}8.4 \\
10.1 \\
9.8 \\
5.5 \\
9.3 \\
-\end{array}$ \\
\hline
\end{tabular}

*Regions identified by superimposing the autoradiographic image and its corresponding section stained with Luxol fast blue/cresyl violet. The regions in the lower group were biopsied to match regions hand-dissected for Table 3 .

+Values represent the number of binding sites labelled by $1 \mathrm{nM}$ $\left[N-\right.$ methyl $\left.-{ }^{3} \mathrm{H}\right]$ citalopram, calculated from the average density calibrated against standards of known radioactivity. Where regions were identified in more than one section, means $\pm S D$ are given.

Table 2. In vivo autoradiography $1 \mathrm{~h}$ after i.v. injection of ( $N$-methyl${ }^{3} \mathrm{H}$ kcitalopram

\begin{tabular}{llc}
\hline Region* & $\begin{array}{l}\text { Total uptaket } \\
\text { (uptake units) }\end{array}$ & $\begin{array}{c}\text { ROI: } \\
\text { cerebellum }\end{array}$ \\
\hline Anterior cingulate & $1.59,1.33$ & 1.57 \\
Frontal cortex & $1.64,1.14$ & 1.49 \\
Caudate putamen & $1.26,1.12$ & 1.28 \\
Thalamus/hypothalamus & $1.39,1.11,1.01$ & 1.26 \\
Hippocampus & $1.40,1.47,1.23$ & 1.46 \\
Amygdala & 1.71 & 1.84 \\
Entorhinal cortex & 1.63 & 1.75 \\
Periaquaductal grey & 1.34 & 1.44 \\
Medulla & 1.16 & 1.25 \\
Cerebellum & $\mathbf{0 . 9 3}$ & - \\
\hline
\end{tabular}

"Regions biopsied to match those dissected.

tTotal uptake reflects both free and non-specifically bound activity plus specific signal. Duplicate or triplicate measurements were taken from coronal sections $1.5 \mathrm{~mm}$ apart. Quantitation was as described for Fig. 3.

\section{In vivo biodistribution}

The time course of the distribution of tritium label was studied by dissection of regions of interest (ROI) followed by radioactivity counting in (1) control rats (given tracer alone), (2) rats predosed with either citalopram hydrobromide or paroxetine hydrochloride, (each at $2 \mathrm{mg} / \mathrm{kg}$ i.v.) and (3) rats chemically lesioned with $p$-chloroamphetamine (PCAP). Figure 4 illustrates the regional efficacy of a dose of $10 \mathrm{mg} / \mathrm{kg}$ PCAP for 3 consecutive days on 5-HT content of homogenates sampled 1 week later. In all lesioned animals, 5-HT was reduced compared to control, but 


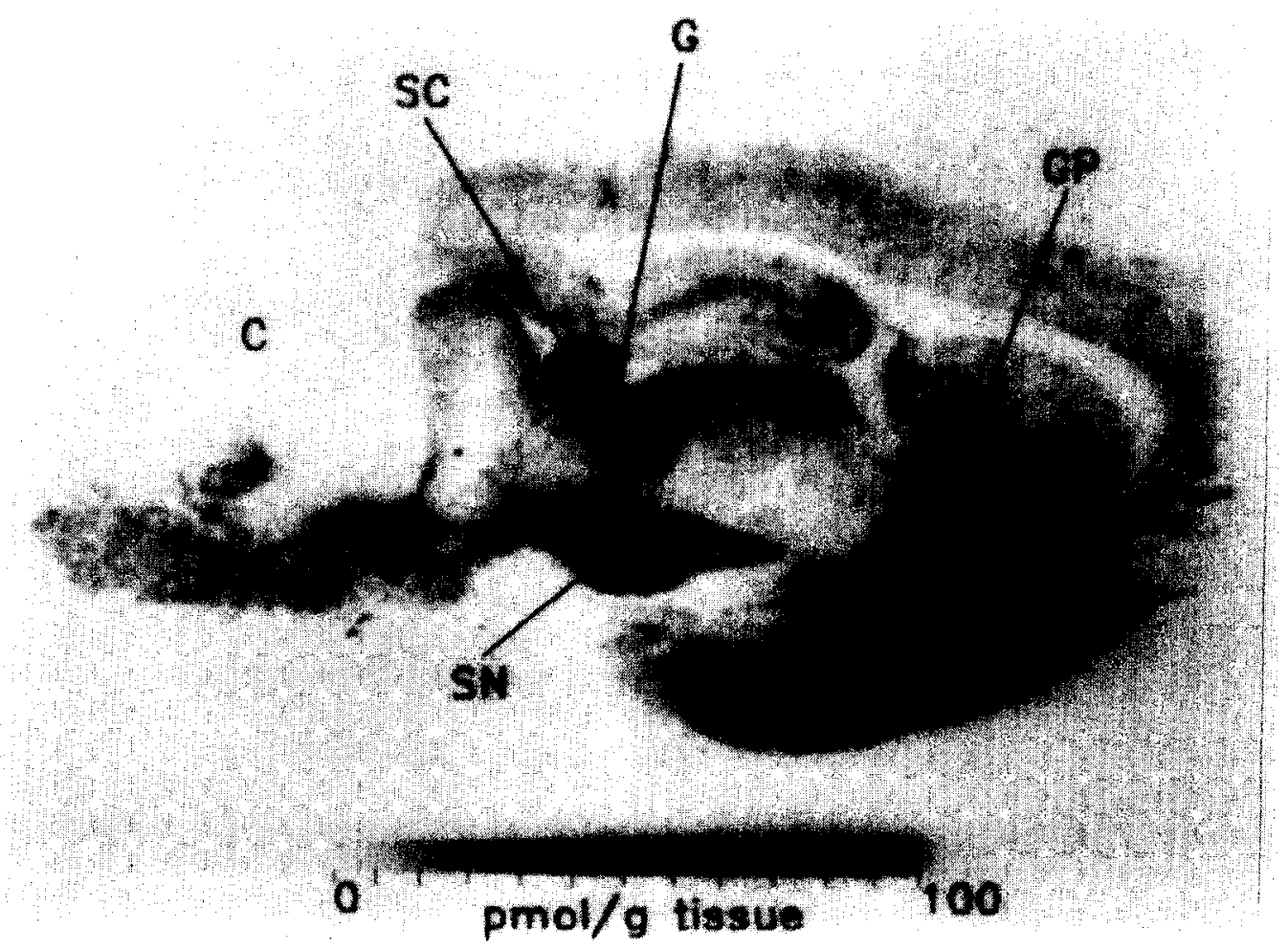

Fig. 2. Digitized image of an in vitro autoradiograph of a $10 \mu \mathrm{m}$ sagital section (lateral $2.9 \mathrm{~mm}$ ) showing high density binding of $\left[N\right.$-methyl $\left.{ }_{-}^{3} \mathrm{H}\right]$ citalopram in substantia nigra (SN), superior colliculus (SC), globus pallidus (GP) and medial geniculate nucleus $(G)$, compared with cerebellum $(C)$. The image was digitized using a Cohu c.c.d. video camera interfaced to a Primagraphics Virtuoso frame store and displayed on a Sun 3/260 work-station using "Analyze" software (Robb and Barillot, 1988). The 8-bit grcy scale (calibrated as $\mathrm{pmol} / \mathrm{g}$ tissue) has been divided arbitrarily into 12 equal units. 


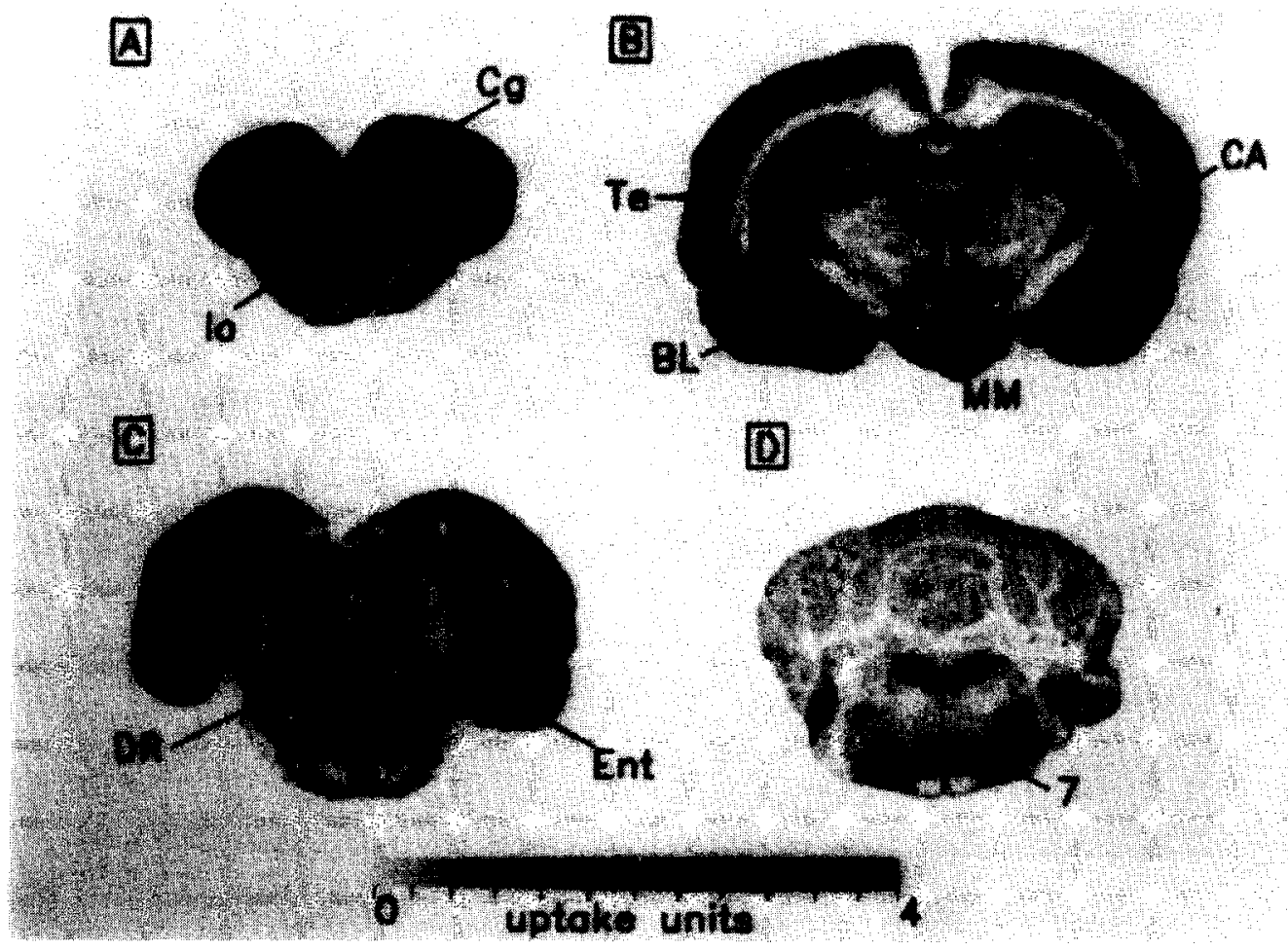

Fig. 3. Digitized images of in vivo autoradiographs of $20 \mu \mathrm{m}$ coronal sections $\mathrm{I}$ h after i.v. injection of [N-methyl $\left.{ }^{3} \mathrm{H}\right]$ citalopram. Stereotaxic coordinates according to Paxinos and Watson (1986) are: (A) 3.7; (B) -4.8 ; (C) -7.6 ; (D) $-10.5 \mathrm{~mm}$. In (A) regions of higher density include cingulate and frontal cortices $(\mathrm{Cg})$ and lateral olfactory tract (lo). In (B) Ammon's horn (CA), mammillary nucleus (MM), basolateral amygdaloid nucleus (BL) and temporal cortex (Te) show high density. In (C) and (D) regions with higher levels of tritium include entorhinal cortex (Ent), dorsal raphe nucleus (DR) and facial nerve (7). The images (digitized as for Fig. 2) were quantified against standards of known radioactivity and the scale recalibrated to uptake units, normalized for total radioactivity injected and the weight of the animal. 


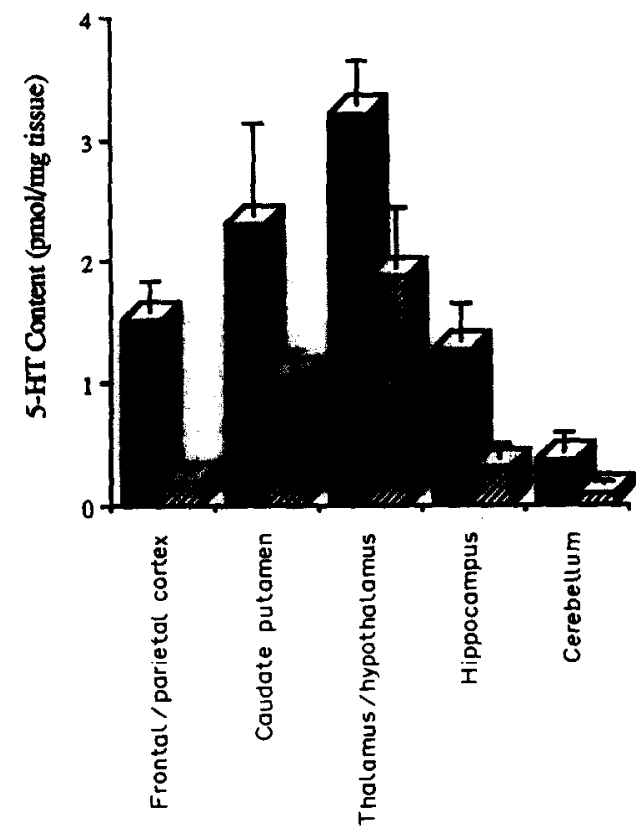

Fig. 4. Mean 5-HT content of homogenates of brain regions from control $\square$ or PCAP lesioned animals. PCAP was given i.p. at a dose of $10 \mathrm{mg} / \mathrm{kg}$ for 3 consecutive days, 1 week prior to assay using HPLC with electrochemical detection. Values are means with SD from 3 to 7 animals. Using Student's $t$-statistic, $P$ values were between $<0.001$ (cortex) and 0.02 (cerebellum).

with a regional variation ranging between a mean reduction of $87 \%$ in frontal cortex to $42 \%$ in thalamus. The 5-HIAA content was reduced similarly so that the ratio 5-HIAA:5-HT was unchanged. Levels of the catecholamines, DA and NA, and the metabolites DOPAC and HVA were not significantly altered in any of the regions assayed (data not shown).

Tritium level in plasma was not altered either by predosing with citalopram or by PCAP lesion (Fig. 5). Initial clearance of radioactivity from plasma

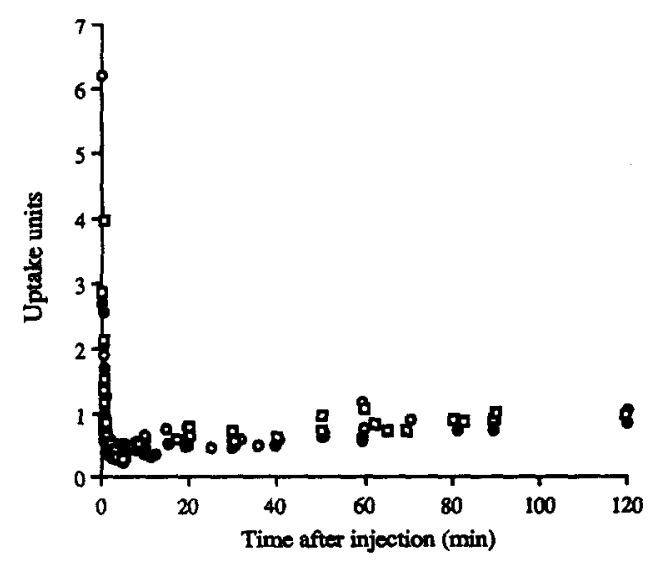

Fig. 5. Plasma content of tritium as a function of time after injection of $\left[\mathrm{N}\right.$-methyl $\left.-{ }^{3} \mathrm{H}\right]$ citalopram given either as a tracer in control $(O)$ or PCAP-lesioned animals $(\square)$ or $10 \mathrm{~min}$ after citalopram HBR at a dose of $2 \mathrm{mg} / \mathrm{kg}$ i.v. (O). The data are from blood samples taken at graded times from each of the rats shown in Fig. 6 ( 5 samples per rat).
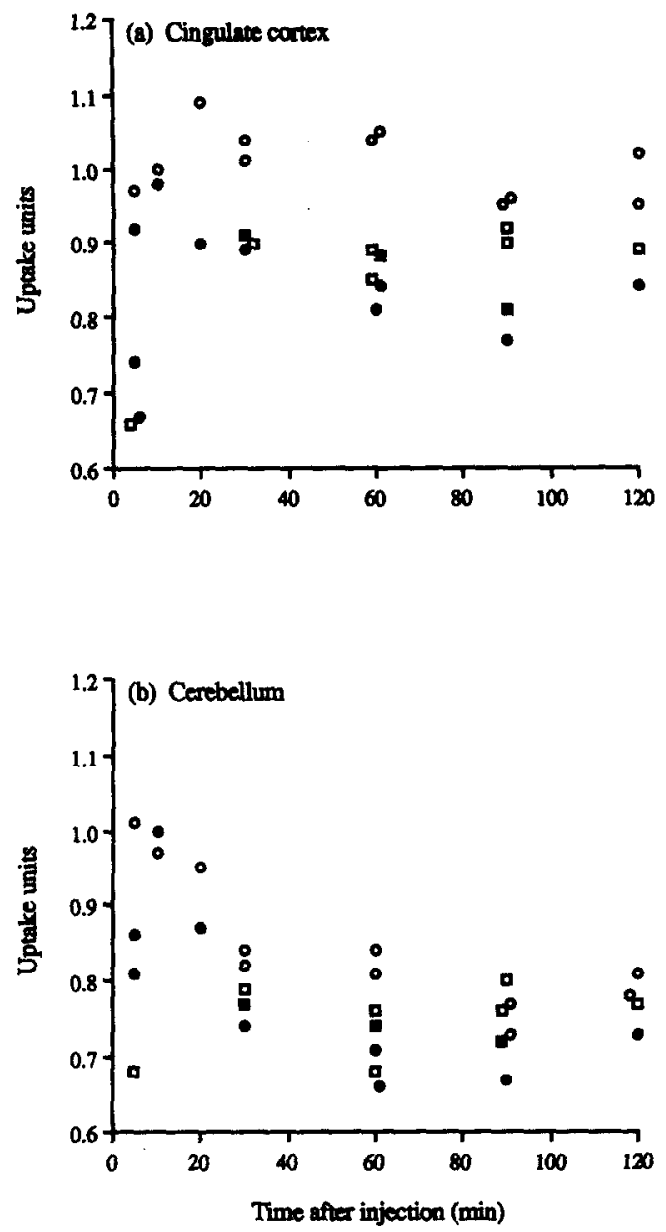

Fig. 6. Uptake in (a) anterior cingulate or (b) cerebellum as a function of time after an i.v. injection of $[N-$ methyl${ }^{3} \mathrm{H}$ jcitalopram in either control $(\mathrm{O}, \mathrm{O})$ or PCAP-lesioned rats $(\square, \square)$ given as either tracer alone (open symbols) or $10 \mathrm{~min}$ after an i.v. injection of $2 \mathrm{mg} / \mathrm{kg}$ citalopram (solid symbols). PCAP was given i.p. at a dose of $10 \mathrm{mg} / \mathrm{kg}$ for 3 consecutive days, 1 week prior to injection of radioactivity. For each figure, one datum point represents one rat. Where data were superimposed, the symbol has been displaced by $1 \mathrm{~min}$ on the abscissa. Uptake units are (Bq/g tissue)/(injected $\mathrm{Bq} / \mathrm{g}$ body weight).

was very rapid but recuperated somewhat between 20-120 min after injection, perhaps reflecting buildup of plasma metabolite(s).

Full time courses for tritium content are detailed for two of the dissected regions, one (cingulate cortex) representing a region with relatively high specific binding and the other (cerebellum) representing a region with low specific uptake (see Table 1 and d'Amato et al., 1987). The initial extraction of radioactivity was similar in the two regions. However, cingulate accumulated tritium over the first $20 \mathrm{~min}$ and retained the tritium for a further $100 \mathrm{~min}$, unlike cerebellum which failed to accumulate tritium over the full span of the experiment (Fig. 6). Predosing the animal with cold citalopram or lesioning with PCAP reduced the tritium label in cingulate, to the extent that predosed or chemically lesioned cingulate had uptake values similar to those of control cerebellum. 
Table 3. Mean uptake values $30-120 \mathrm{~min}$ after i.v. injection of $\left[N-\right.$ methyl $\left.-{ }^{3} \mathrm{H}\right]$ citalopram

\begin{tabular}{|c|c|c|c|c|}
\hline \multirow[b]{3}{*}{ Region } & \multicolumn{4}{|c|}{ Uptake* } \\
\hline & \multicolumn{2}{|c|}{ Control } & \multicolumn{2}{|c|}{ PCAP-lesioned } \\
\hline & Tracer alone & Predosed & Tracer alone & Predosed \\
\hline Cingulate cortex & $1.00 \pm 0.04(8)$ & $0.83 \pm 0.05(5)$ & $0.90 \pm 0.03(6)$ & $0.87 \pm 0.05(3)$ \\
\hline Olfactory lobes & $0.85 \pm 0.04(8)$ & $0.70 \pm 0.03(5)$ & $0.79 \pm 0.06(6)$ & $0.75 \pm 0.02(3)$ \\
\hline Frontal cortex & $0.96 \pm 0.05(8)$ & $0.79 \pm 0.05(5)$ & $0.86 \pm 0.05(6)$ & $0.84 \pm 0.04$ \\
\hline Entorhinal cortex & $0.97 \pm 0.09(6)$ & $0.80 \pm 0.08(3)$ & $0.88 \pm 0.01$ & $0.85 \pm 0.06(3)$ \\
\hline Caudate putamen & $0.91 \pm 0.04(8)$ & $0.74 \pm 0.03(5)$ & $0.81 \pm 0.05(6)$ & $0.79 \pm 0.05(3)$ \\
\hline Septum & $0.95 \pm 0.04(6)$ & $0.76 \pm 0.02(3)$ & $0.84 \pm 0.02(3)$ & $0.83 \pm 0.02$ \\
\hline Thalamus & $0.93 \pm 0.04(8)$ & $0.74 \pm 0.03(5)$ & $0.84 \pm 0.06(6)$ & $0.77 \pm 0.02(3)$ \\
\hline Hippocampus & $0.93 \pm 0.06(8)$ & $0.78 \pm 0.05(5)$ & $0.83 \pm 0.05(6)$ & $0.82 \pm 0.02(3)$ \\
\hline Sup. colliculi & $0.98 \pm 0.05(6)$ & $0.71 \pm 0.04(3)$ & $0.84 \pm 0.02(3)$ & $0.75 \pm 0.06(3)$ \\
\hline Medulla & $0.87 \pm 0.03(8)$ & $0.69 \pm 0.04(5)$ & $0.76 \pm 0.04(6)$ & $0.73 \pm 0.04(3)$ \\
\hline Inf. colliculi & $0.95 \pm 0.07(7)$ & $0.76 \pm 0.05(3)$ & $0.85 \pm 0.03(3)$ & $0.76 \pm 0.05$ \\
\hline Periaqua. grey & $0.94 \pm 0.08(6)$ & $0.72 \pm 0.04(3)$ & $0.94 \pm 0.07(3)$ & $0.75 \pm 0.03(3)$ \\
\hline Cerebellum & $0.80 \pm 0.04(8)$ & $0.70 \pm 0.04(5)$ & $0.76 \pm 0.04(6)$ & $0.74 \pm 0.03(3)$ \\
\hline
\end{tabular}

At the present time, kinetic modelling of radioligand binding is not feasible because of (a) the considerable scatter in the data obtained from these preliminary "screening" studies and (b) the lack of blood metabolite analysis. Therefore, regional differences in radioligand binding have been assessed as mean uptake values obtained 30-120 min after injection (Table 3). Over this period, there was no significant effect of time on uptake values, in any of the treatment groups. Predosing with cold drug caused a significant reduction in tritium uptake in each region shown, including cerebellum, compared with control (Student's $t$-test, $P<0.001$, except in entorhinal cortex where $P=0.02$ ). PCAP-lesioned rats also showed a significantly reduced uptake in the majority of regions (grouped in Table 3 as cingulate cortex to medulla), although to a smaller extent. Predosing had no further effect $(P>0.1)$. In inferior colliculi and periaquaductal grey, PCAP was ineffective at reducing tritium uptake and, in these regions, predosing the lesioned animals resulted in uptake levels similar to those in predosed controls.

PCAP lesioning had no significant effect on uptake in cerebellum $(P>0.1)$. The reduction in cerebellar uptake in citalopram-predosed animals $(P<0.001)$ may indicate a change in regional delivery of radioligand following a pharmacologically active dose of drug rather than reflecting a specific signal in this region. Similar problems were associated with tritium uptake following predosing with paroxetine but, in this case, total uptake values were increased in all sampled regions and, in addition, administration of paroxetine significantly altered plasma radioactivity levels (data not shown). Thus a comparison of the effects of paroxetine-relative to citaloprampredosing on $\left[\mathrm{N}\right.$-methyl $\left.-{ }^{3} \mathrm{H}\right]$ citalopram binding was only possible using ratios of uptake ROI : cerebellum rather than absolute uptake values. It is, however, doubtful whether the use of cerebellum as a reference tissue can be justified because of apparent regional variations in the non-specific uptake (Table 3). In Table 4, the regions presented have been limited to those with local blood flow values similar to that of cerebellum (Cremer and Seville, 1983). As can be seen, the reduction in specific signal in the presence of paroxetine was very similar to that obtained by predosing with citalopram.

\section{(2) Radiosynthesis and Characterization of [N-methyl- ${ }^{11}$ CJCitalopram}

\section{Production of $\left[{ }^{11}\right.$ C carbon dioxide}

$\left[{ }^{11} \mathrm{C}\right]$ Carbon dioxide was produced with the MRC Scanditronix MC 40 (mark II) cyclotron by the ${ }^{14} \mathrm{~N}(\mathrm{p}, \alpha){ }^{11} \mathrm{C}$ nuclear reaction on nitrogen $(99.95 \%$ purity; $G$ and $E$ Union Carbide; predried by passage

Table 4. Effect of predosing with either citalopram or paroxetine on ROI:cerebellum ratio

\begin{tabular}{lccc}
\hline & \multicolumn{3}{c}{ ROI:cerebellum (uptake 30-120 min)* } \\
\cline { 2 - 4 } Region & Control & \multicolumn{2}{c}{ Predosed } \\
\cline { 2 - 4 } Caudate putamen & $1.14 \pm 0.05(8)$ & $1.05 \pm 0.03(8)$ & $1.01,1.09$ \\
Thalamus & $1.17 \pm 0.05(8)$ & $1.05 \pm 0.03(8)$ & $1.00,1.07$ \\
Superior colliculi & $1.23 \pm 0.08(6)$ & $1.00 \pm 0.04(6)$ & $1.03,1.07$ \\
Periaqua. grey & $1.17 \pm 0.08(6)$ & $1.01 \pm 0.02(6)$ & $1.03,1.07$ \\
Hippocampus & $1.16 \pm 0.08(8)$ & $1.11 \pm 0.04(8)$ & $0.95,1.16$ \\
Medulla & $1.09 \pm 0.02(8)$ & $0.98 \pm 0.02(8)$ & $0.98,1.01$ \\
\hline
\end{tabular}

*Values are means with standard deviations from the number of rats shown in parentheses, killed at $30,60,90$ or $120 \mathrm{~min}$ after injection of $\left[N \cdot\right.$ methyl $\left.{ }^{3} \mathrm{H}\right]$ citalopram. The two paroxetinedosed rats were killed at 30 or $60 \mathrm{~min}$ after injection. Predosed rats were given $2 \mathrm{mg} / \mathrm{kg}$ cold drug i.v., $10 \mathrm{~min}$ prior to $\left[N \cdot \mathrm{methyl}^{-}{ }^{3} \mathrm{H}\right] \mathrm{citalopram}$ 
through magnesium perchlorate) at $1333 \mathrm{kN} / \mathrm{m}^{2}$ (200 psi). Bombardment was carried out for 3-30 min with $19 \mathrm{MeV}$ protons with a beam current set between $10-30 \mu \mathrm{A}$. At the end of bombardment (EOB) the target was vented over $c .1 .5 \mathrm{~min}$ into a loop $(2.4 \mathrm{~cm}$ dia, 2 turns) of stainless steel tube $(0.73 \mathrm{~mm}$ i.d.) that had been preflushed with dry nitrogen and kept immersed in liquid argon.

\section{Production of $\left[{ }^{\prime \prime}\right.$ Cliodomethane}

$\left[{ }^{11} \mathrm{C}\right]$ Iodomethane was prepared from trapped [" C]carbon dioxide essentially in remotely controlled apparatus. Briefly, the procedure involves the reaction of $\left[{ }^{11} \mathrm{C}\right]$ carbon dioxide with lithium aluminium hydride in tetrahydrofuran $(10 \mathrm{mg} / \mathrm{mL}, 200 \mu \mathrm{L})$, hydrolysis of the radioactive adduct to $\left[{ }^{11} \mathrm{C}\right]$ methanol and conversion of this into $\left[{ }^{11} \mathrm{C}\right]$ iodomethane by treatment with hydroiodic acid $(55 \%, 150 \mu \mathrm{L})$ in one pot, essentially as recommended by Crouzel et al. (1987). The time required for this preparation is $10 \mathrm{~min}$ from $\mathrm{EOB}$ and gives $\mathrm{nca}\left[{ }^{11} \mathrm{C}\right]$ iodomethane in $60-80 \%$ radiochemical yield (decay corrected) from cyclotron-produced carbon dioxide.

\section{Preparation of nca [N-methyl-"C]citalopram}

$\left[{ }^{11} \mathrm{C}\right]$ Iodomethane was dispensed by a slow flow of nitrogen into a vented vial (volume $900 \mu \mathrm{L}$ ) containing ethanol $(400 \mu \mathrm{L}), 2,2,6,6$-tetramethylpiperidine $(3 \mu \mathrm{L}, \quad 18 \mu \mathrm{mol})$, norcitalopram hydrochloride (4.5 mg, $15.5 \mu \mathrm{mol}$ ) and a magnetic follower. The collected radioactivity was monitored and the vial sealed when the radioactivity reached a maximum (about $1.5 \mathrm{~min}$ ). The reaction vessel was then heated at $95^{\circ} \mathrm{C}$ with magnetic stirring for $5 \mathrm{~min}$. Heating was then stopped and the reaction vessel vented to allow nitrogen to be passed through the solution for $1 \mathrm{~min}$, so removing much residual $\left[{ }^{11} \mathrm{C}\right]$ iodomethane and reducing the volume to about $100 \mu \mathrm{L}$. (In separate experiments the residue was generally found to contain about $60 \%$ of the initial radioactivity in nonvolatile chemical form, corrected for physical decay.) The residual solution was taken up into chloroform $(1.5 \mathrm{~mL})$ and injected onto a silica gel column $(30 \times 0.7 \mathrm{~cm}$ i.d.; particle size $10 \mu \mathrm{m}, " \mu$-Porasil", Waters Associates, U.K.), eluted at $3 \mathrm{~mL} / \mathrm{min}$ with chloroform/methanol $(9: 1$ by vol). The eluate was monitored continuously for radioactivity and for absorbance at $254 \mathrm{~nm}$. The radioactive fraction having the same retention time as authentic citalopram $(8 \mathrm{~min})$ was collected, rotary evaporated to dryness and dissolved with normal saline for injection $(9.8 \mathrm{~mL} ; 0.9 \% \mathrm{v} / \mathrm{v} \mathrm{NaCl}$. BP, Boots Ltd, U.K.) plus absolute ethanol $(0.2 \mathrm{~mL})$. The $\mathrm{pH}$ of the resultant solution was $c$. 6.5. The radiochemical yield of injectable solution was c. $49 \%$ from $\left[{ }^{11}\right.$ C]iodomethane (decay-corrected) in an overall preparation time of $40 \mathrm{~min}$ from EOB.

The labelled biologically active isomer, (+)-[Nmethyl ${ }^{11} \mathrm{C}$ citalopram, was prepared by exactly the same procedure from $(+)$-norcitalopram oxalate.

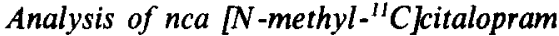

(1) By HPLC. A sample $(100 \mu \mathrm{L})$ of the formulated product was analysed by reverse phase HPLC, using a Nucleosil $5 \mathrm{C}_{18}$ column $(25 \times 0.46 \mathrm{~cm}$ i.d.; particle size $5 \mu \mathrm{m}$, Technicol Ltd, U.K.) eluted with aqueous potassium dihydrogen phosphate solution $(0.07 \mathrm{M})$-acetonitrile $(7 / 13 \mathrm{by}$ vol) at $1 \mathrm{~mL} / \mathrm{min}$, with eluate monitored for radioactivity and for absorbance at $254 \mathrm{~nm}$. The main radioactive peak contained over $99 \%$ of the radioactivity and had the same retention time $(9.33 \mathrm{~min})$ as authentic citalopram. The corresponding absorbance peak represented over $99 \%$ of the integrated absorbance for the sample. No norcitalopram (retention time, $8.3 \mathrm{~min}$ ) was detected.

The response of the absorbance detector at $254 \mathrm{~nm}$ was precalibrated with respect to mass by measuring peak areas for known masses of authentic citalopram hydrobromide in order to allow the mass of citalopram $\left(M_{c}, \mu \mathrm{mol}\right)$ in the analyte to be calculated. The radioactive peak was measured for radioactivity $\left(A_{c}\right.$, $\mathrm{GBq}$ ) in a calibrated high pressure ionization chamber at a known time ( $t \mathrm{~min})$ from EOB. The specific activity of citalopram $\left(S_{c}\right)$ at EOB was then calculated as

$$
S_{\mathrm{c}}=\left(A_{\mathrm{c}} / M_{\mathrm{c}}\right) \mathrm{e}^{0.034 t} \quad(\mathrm{GBq} / \mu \mathrm{mol}) .
$$

$S_{\mathrm{c}}$ increased in relation to the initial radioactivity produced at EOB. The highest value of $S_{\mathrm{c}}(59 \mathrm{GBq} /$ $\mu \mathrm{mol} 1.6 \mathrm{Ci} / \mu \mathrm{mol}$ decay-corrected to EOB) was obtained from radioactivity produced from a $30 \mathrm{~min}$ irradiation with a $30 \mu \mathrm{A}$ beam of $19 \mathrm{MeV}$ protons.

(2) By TLC. A sample of the radioactive fraction from preparative HPLC was analysed by TLC on silica gel (CAMLAB Polygram SIL G/UV 254) developed in toluene/ethanol/triethylamine $(5: 5: 0.1 \mathrm{v} / \mathrm{v})$ and on reverse phase precoated TLC plates (Merck, RP-18 $\mathrm{F}_{254}$ ) developed in methanol/c. ammonium hydroxide ( $99: 1$ by vol). the product was found to be chemically and radiochemically pure and to comigrate with reference citalopram.

(3) By mass spectrometry. A sample of the formulated product was, after radioactive-decay, examined by mass spectrometry (C.I., $\mathrm{NH}_{3} 1$ torr; E.I., $70 \mathrm{eV}$ ). The obtained spectrum was attributable to carrier citalopram. i.e. $m / z 325\left([\mathrm{M}+1]^{+}, 100 \%\right) ; 238([\mathrm{M}-$ $\left.\left.\mathrm{CH}_{3} \mathrm{CH}_{2} \mathrm{CH}_{2} \mathrm{~N}(\mathrm{Me})_{2}\right]^{+}, 83 \%\right) ; 221 \quad\left([238-\mathrm{OH}]^{+}\right.$, $25 \%) ; 208\left(\left[238-\mathrm{CH}_{2} \mathrm{O}\right]^{+}, 43 \%\right)$.

(4) Further validation of the radiosynthesis. The radiosynthesis of $\left[\mathrm{N}\right.$-methyl $\left.-{ }^{11} \mathrm{C}\right] \mathrm{citalopram}$ was carried out as described above but with the co-inclusion of ${ }^{13} \mathrm{C}$-enriched $(90$ atom $\%)$ iodomethane $(1.2 \mu \mathrm{L}$; Amersham International plc, U.K.). The collected radioactive fraction from HPLC, containing a mixture of ${ }^{11} \mathrm{C}$ - and ${ }^{13} \mathrm{C}$-labelled product, was examined by proton-decoupled Fourier transform ${ }^{13} \mathrm{C}-\mathrm{NMR}$ spectroscopy $\left(62.9 \mathrm{MHz} ; \mathrm{d}_{6}\right.$-DMSO) with multiplicity determined by DEPT editing and gave a single intense peak $\left(\delta_{\mathrm{TMS}}=44.9 \mathrm{ppm}\right)$ attributable to a methyl 


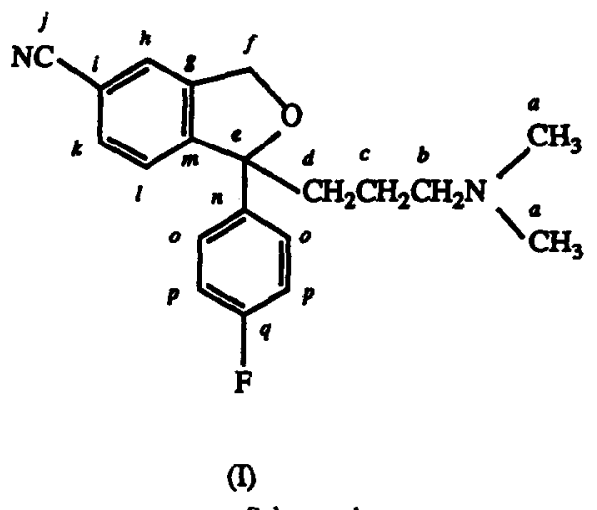

Scheme 1

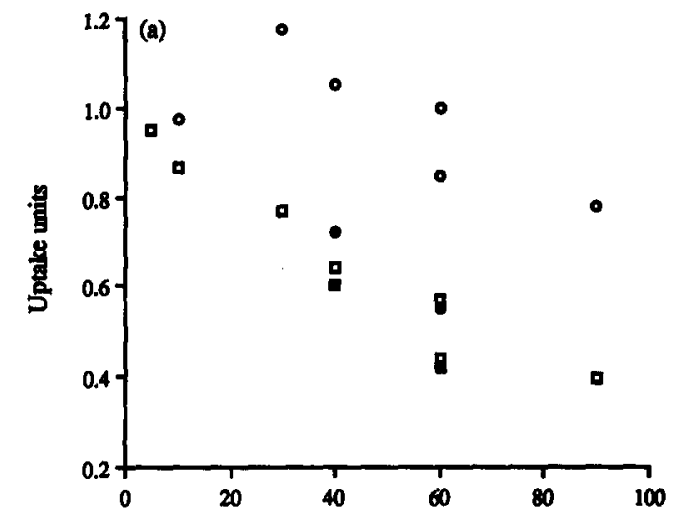

carbon. For comparison authentic citalopram hydrobromide gave $\delta_{\mathrm{TMS}}=42.1(\mathrm{Me} ; a), 56.5\left(\mathrm{CH}_{2} ; b\right), 19.1$ $\left(\mathrm{CH}_{2}, c\right), 36.8\left(\mathrm{CH}_{2}, d\right), 90.2$ (quaternary $\left.\mathrm{C}, e\right), 71.1$ $\left(\mathrm{CH}_{2}, f\right), 139.8 / 148.7$ (quaternary $\mathrm{Cs}, \mathrm{g} / \mathrm{m}$ ), 132.0/125.7/123.1 (CHs, $h / k / l$ ), 110.6 (quaternary C, i), $118.6(\mathrm{CN}, j), 139.9$ (doublet, quaternary $\mathrm{C}$, $J_{\mathrm{C}-\mathrm{F}}=3.0 \mathrm{~Hz}, n$ ), 126.9 (doublet, $\mathrm{CH}, J_{\mathrm{C}-\mathrm{F}}=8.1 \mathrm{~Hz}$, o), 115.1 (doublet, $\mathrm{CH}, J_{\mathrm{C}-\mathrm{F}}=21.1 \mathrm{~Hz}, p$ ), 161.3 (doublet, quaternary $\mathrm{C}, J_{\mathrm{C}-\mathrm{F}}=243.6 \mathrm{~Hz}, q$ ) (see Scheme 1).

\section{(3) Biological Studies with nca $\left[N-\right.$ methyl $\left.-{ }^{11} \mathrm{C}\right]$ - Citalopram}

For experiments using nca [ $N$-methyl$\left.{ }^{11} \mathrm{C}\right] \mathrm{citalopram}$, either as racemate or pure biologically active enantiomer, each rat received $250 \mu \mathrm{L}$ saline containing $7.9 \mathrm{MBq}$. Rats were sacrificed and the brain regions dissected as in the experiment with tritiated radioligand. Blood and brain samples were counted using a LKB Wallac 1282 gamma counter with automatic decay correction. Table 5 compares the regional distribution of racemic [N-methyl${ }^{11}$ C]citalopram with that of racemic [N-methyl${ }^{3} \mathrm{H}$ ]citalopram at $60 \mathrm{~min}$. Figure $7(\mathrm{a})$ compares the uptake of the pure entantiomer, (+)-[N-methyl${ }^{11}$ C]citalopram, at times up to $90 \mathrm{~min}$ after i.v. injection, in thalamus compared to that in cerebellum. Figure 7(b) shows uptake ratio (thalamus: cerebellum) as a function of time after injection. The ratio

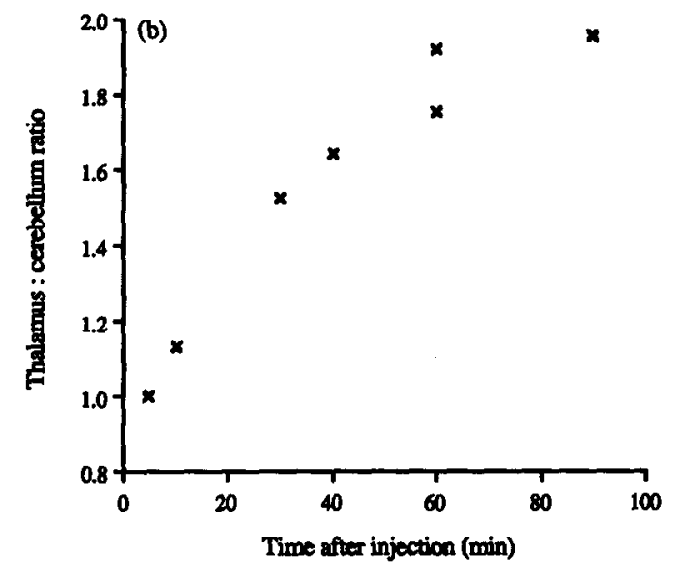

Fig. 7. (a) Uptake of $(+)-[N-$ methyl $-" C]$ citalopram in thalamus $(O, O)$ or cerebellum $(\square, \square)$ as a function of time after injection in either control rats (open symbols) or rats predosed with citalopram $(\mathrm{HBr}), 2 \mathrm{mg} / \mathrm{kg}$, i.v., $10 \mathrm{~min}$ prior to injection (solid symbols). One datum point represents one rat. (b) Ratio of uptake in thalamus compared with that in cerebellum as a function of time after injection of $(+)-[N-$ methyl $-{ }^{11} \mathrm{C}$ ]citalopram.

of uptake in region of interest to that in cerebellum at 90 min rank, in order of "specific signal", as thalamus (1.95), frontal cortex (1.68), caudate putamen (1.60), hippocampus (1.55), medulla (1.50) and olfactory lobes (1.25).

Table 5. Regional distribution of $[N-$ methyl-" C]citalopram compared with [N-methyl${ }^{3}$ H Jcitalopram

\begin{tabular}{|c|c|c|c|c|}
\hline \multirow[b]{3}{*}{ Region } & \multicolumn{4}{|c|}{60 min Uptake } \\
\hline & \multicolumn{2}{|c|}{ Tracer alone } & \multicolumn{2}{|c|}{ Predosed } \\
\hline & ${ }^{3} \mathrm{H}$-label & "C-label & ${ }^{3} \mathrm{H}$-label & "C-label \\
\hline $\begin{array}{l}\text { Olfactory lobes } \\
\text { Frontal cortex } \\
\text { Thalamus } \\
\text { Caudate putamen } \\
\text { Hippocampus } \\
\text { Medulla } \\
\text { Cerebellum }\end{array}$ & $\begin{array}{l}0.88,0.87 \\
1.02,1.01 \\
0.96 .0 .96 \\
0.98,0.96 \\
1.03,0.99 \\
0.89,0.90 \\
0.81,0.84\end{array}$ & $\begin{array}{l}0.83,0.82 \\
1.06 .1 .05 \\
1.05,1.08 \\
1.01,1.07 \\
1.02,0.99 \\
0.96,0.90 \\
0.75,0.77\end{array}$ & $\begin{array}{l}0.71,0.65 \\
0.82,0.76 \\
0.77,0.72 \\
0.76,0.71 \\
0.85,0.73 \\
0.71,0.64 \\
0.71,0.66\end{array}$ & $\begin{array}{l}0.65,0.61 \\
0.82,0.76 \\
0.78,0.72 \\
0.74,0.72 \\
0.76,0.72 \\
0.69,0.62 \\
0.62,0.59\end{array}$ \\
\hline
\end{tabular}

Each vertical column represents regional variation in one rat, $60 \mathrm{~min}$ after injection of either $\left[N-\right.$-methyl- $\left.{ }^{3} \mathrm{H}\right]$ citalopram or $\left[N-\right.$ methyl $\left.{ }^{11}{ }^{11} \mathrm{C}\right]$ citalopram (2 rats per treatment group). Predosed rats were given citalopram $\mathrm{HBr}(2 \mathrm{mg} / \mathrm{kg}$ i.v. $), 10 \mathrm{~min}$ prior to the radioisotope. Plasma levels of radioactivity were not significantly different over the $60 \mathrm{~min}$. 


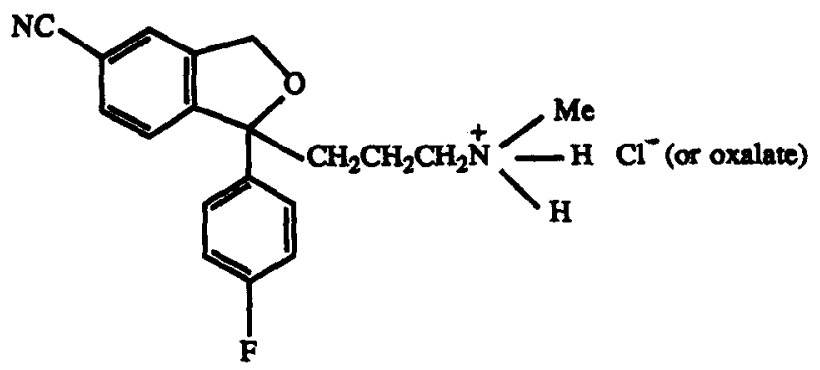

N-Desmethyl-citalopram hydrochloride (or oxalate)

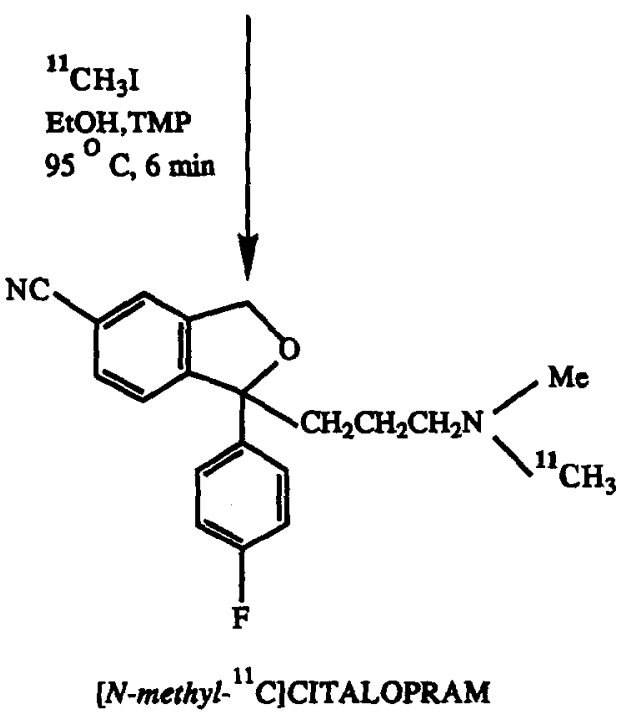

Scheme 2. Radiosynthesis of [N-methyl $\left.-{ }^{11} \mathrm{C}\right]$ citalopram.

\section{Discussion}

As a preliminary evaluation of the potential of citalopram as a PET radioligand, the reported biological studies with $\left[N\right.$-methyl $\left.{ }^{3} \mathrm{H}\right]$ citalopram were designed to confirm the selectivity of citalopram for the serotonergic system, to check the localisation of specific binding in an experimental model and to quantitate regional binding in vivo.

Microdialysis studies gave evidence for functional selectivity predicted from earlier in vitro reports (Hyttel, 1982). Technical and practical aspects of brain microdialysis have recently been reviewed by Benveniste (1989). Of specific relevance is the conclusion of Sharp et al. (1989) that, under conditions where dialysate levels of 5-HT are constant, the spontaneous output of endogenous 5-HT predominantly originates from central 5-HT neurons.

In the present in vitro study, high densities of specific binding of $\left[N-\right.$ methyl $\left.{ }^{3} \mathrm{H}\right]$ citalopram were observed in olfactory tubercles, amygdaloid nuclei, superficial grey of the superior colliculi, substantia nigra and in the medial forebrain bundle. The regional localization is in agreement with that previously described by d'Amato et al. (1987) and correlates with the mapping of serotonergic structures (e.g. Palkovits et al., 1981; Savaki et al., 1985). Cerebellar cortex appeared almost devoid of $[N$ - methyl $-{ }^{3} \mathrm{H}$ citalopram binding sites and the binding ratios (ROI: cerebellum) were of the order of 9 . The regional distribution of $\left[{ }^{3} \mathrm{H}\right]$ citalopram in post mortem human brain has recently been described by Plenge et al. (1990).

Although in vitro autoradiography served to localize a specific signal, in vivo binding studies, by including non-specific labelling, are more indicative of likely PET images. As illustrated in Fig. 3, in vivo extraction of $\left[\mathrm{N}\right.$-methyl $\left.{ }^{3} \mathrm{H}\right]$ citalopram into rat brain was low with relatively high labelling in the choroid plexus. In contrast to results from in vitro binding, significant labelling was obtained in the cerebellum. In the absence of the corresponding autoradiography from a rat predosed with the cold drug, it can be assumed that the majority of this "additional" uptake is not specifically bound. There are some identifiable high density regions, for example the mammillary nucleus, giving a 3-fold greater uptake value than cerebellum. However, for the majority of regions of interest the uptake value is only 1.5 -fold greater.

When assessing temporal biodistribution in vivo, total label was measured by giving tracer alone and regional specificity estimated by predosing the rat with citalopram. Selectivity was checked by predosing with paroxetine and by measuring uptake of tracer in PCAP-lesioned animals. The latter drug has a long-term cytotoxic effect that is selective to 5-HT 
neurons, resulting in degeneration of both cell bodies and axon terminals (Saunders-Bush and Steranka, 1978). Representative data for uptake as a function of time after injection are presented in Fig. 6. Regional variation in in vivo uptake was consistent with a distribution of specific binding similar to that described in vitro. However, the relatively large nonspecific labelling resulted in only a relatively small specific signal within the span of the experiment. In control animals, the ratio of uptake in cingulate relative to that in cerebellum was greater than unity after approx. $10 \mathrm{~min}$ and reached a maximum of $1.2-1.3$ over $30-120 \mathrm{~min}$ after injection. These results were obtained with racemic $\left[\mathrm{N}\right.$-methyl $\left.{ }^{3} \mathrm{H}\right]$ citalopram. It is now known that only one of the enantiomers is a potent 5-HT re-uptake inhibitor (J. Hyttel, personal communication). The use of the single biologically active $(+)$-enantiomer in these experiments would have been expected to give greater uptake ratios. These biological observations and the recent availability of a suitable precursor in enantiomerically pure form therefore prompted us to develop a procedure for labelling citalopram with carbon-11, based on the $\left[{ }^{11} \mathrm{C}\right]$ methylation of norcitalopram with nca $\left.{ }^{1 \mathrm{l}} \mathrm{C}\right]$ iodomethane (Scheme 2), an easily accessible labelling agent (Crouzel et al., 1987).

Normally the labelling of a tertiary $N$-methyl amine with carbon- 11 is best achieved by $N$-methylation of the free base of the corresponding nor-compound with $\left[{ }^{11} \mathrm{C}\right]$ iodomethane. No added base is required and work up of reaction simply involves removal of volatiles and then HPLC. However, it has not proved possible to crystallize norcitalopram as the free base for storage. To enable norcitalopram to react with $\left[{ }^{11} \mathrm{C}\right]$ iodomethane, we therefore liberated the free base from the salt in situ by including an excess of the sterically-hindered base, 2,2,6,6tetramethyl-piperidine (TMP). Generally in $N$ ["C]methylations of amines with [" C]iodomethane lower radiochemical yields are obtained when TMP has to be present to liberate the free base than if the free base is used alone (Langström et al., 1982; Lasne et al., 1989). However, the decay-corrected radiochemical yields of $\left[\mathrm{N}\right.$-methyl $\left.{ }^{11} \mathrm{C}\right]$ citalopram were very satisfactory, averaging $59 \%$ from $\left[{ }^{11} \mathrm{C}\right]$ iodomethane with ethanol as solvent. The use of DMSO as solvent gave an even higher decay-corrected radiochemical yield (c. $70 \%$ ). However, ethanol is the solvent of choice because it allows faster work-up with fewer operations.

The concentration of precursor in the reaction medium was progressively varied over several preparations to assess the effect of radiochemical yield. It was observed that at a concentration lower than $10 \mathrm{mg} / \mathrm{mL}(32 \mathrm{mM})$ radiochemical yields decreased drastically whereas, above $14 \mathrm{mg} / \mathrm{mL}$ ( $45 \mathrm{mM}$ ), radiochemical yield did not improve. The preparation was "worked up" by removing nearly all ethanol, separating product by preparative HPLC, evaporating solvent and formulation. During the evaporation of ethanol, particular care was taken not to remove all solvent. By leaving $100 \mu \mathrm{L}$ of solvent subsequent dissolution of the product in HPLC mobile phase was rendered efficient; otherwise a large proportion of radioactivity was left on the walls of the reaction vessel.

For the described animal experiments no sterilization of the formulated product was necessary. However, it was noted that during passage of $2 \mathrm{~mL}$ of formulated product through a Millex GS filter (pore size, $0.22 \mu \mathrm{m}$; Millipore Corp., U.K.) $42 \%$ of the radioactivity was retained on the filter. A similar result ( $44 \%$ of retention of radioactivity) was obtained through use of a Millex FG filter (pore size, $0.2 \mu \mathrm{m}$; Millipore Corp.) preconditioned with $5 \mathrm{~mL}$ of ethanol and then $10 \mathrm{~mL}$ of water. This loss is less $(17 \%)$ if the formulated solution is diluted to $10 \mathrm{~mL}$ with isotonic saline $(2 \%)$ before filtration through a Millex SG filter. Such a volume is of course easily acceptable for human i.v. administration. All formulated products treated in this way were found to be apyrogenic and sterile in independent tests.

The analytical results from radiochromatography, and from mass spectrometry and ${ }^{13} \mathrm{C}-\mathrm{NMR}$ spectroscopy on carrier, unequivocally demonstrate the radiochemical and chemical purity of the separated product. The described HPLC method of analysis is rapid, delivers information on the radiochemical purity, chemical purity and specific activity of formalized product and is therefore suitable for routine application. It should be noted however that it is especially important to use tetrahydrofuran, rather than diethyl ether, as solvent for lithium aluminium hydride in the preparation of [ $\left.{ }^{11} \mathrm{C}\right]$ iodomethane. This avoids any possibility of producing the difficulty scparablc $N$-ethyl-norcitalopram which can be formed when diethyl ether is used.

The described radiosynthesis easily produces $[N$ methyl ${ }^{11} \mathrm{C}$ ]citalopram in activity and specific activity sufficient for preliminary evaluation as a PET radioligand for the study of the serotonin re-uptake sites in man. It is also amenable to full remote-control for radiation safety in the manner described by Clark $e t$ al. (1989).

Uptake values of racemic $\left[N-\right.$ methyl $\left.-{ }^{11} \mathrm{C}\right]$ citalopram were similar to those for $\left[N-\right.$ methyl $\left.-{ }^{3} \mathrm{H}\right]$ citalopram in the majority of dissected regions (see Table 5). There was some indication of a smaller non-specific contribution to total uptake using the ${ }^{11} \mathrm{C}$-compound, as evidenced by lower tracer uptake into cerebellum. This, together with a slightly greater uptake in regions of interest, resulted in a relatively larger specific signal. Compared to the " ${ }^{~} \mathrm{C}$-labelled racemate the "C-labelled biologically active entantiomer of citalopram gave enhanced specific signal in the rat following i.v. injection, the ratio of uptake in regions of interest to cerebellum approaching 2 at $90 \mathrm{~min}$ (Fig. 7). In conclusion, these studies show that citalopram can be labelled efficiently with carbon-11, either as the racemate or as the single biologically 
active enantiomer, and provide biological evidence for the potential of the labelled pure enantiomer as a PET radiologand for 5-HT re-uptake sites.

Acknowledgements - Citalopram hydrobromide (Lu 10171B), norcitalopram hydrochloride, (+)-norcitalopram oxalate and $( \pm)-\left[N-\right.$ methyl $\left.-{ }^{3} \mathrm{H}\right]$ citalopram $(2.54 \mathrm{GBq} / \mu \mathrm{mol}$; $37 \mathrm{kBq} / \mu \mathrm{L}$ in ethanol) were kindly donated by Drs $\mathrm{K}$. Begesø and J. Hyttel of H. Lundbeck A/S, CopenhagenValby, Denmark. The authors are grateful to Dr S. L. Waters for performing mass spectrometry, and to Mrs J. Hawkes and Mrs F. Gallwey (King's College, London) for performing NMR spectroscopy.

\section{References}

d'Amato R. J., Largent B. L., Snowman A. M. and Snyder S. H. (1987) Selective labelling of serotonin uptake sites in rat brain by $\left[{ }^{3} \mathrm{H}\right]$ citalopram contrasted to labelling of multiple sites by $\left[{ }^{3} \mathrm{H}\right]$ imipramine. J. Pharmacol. Exp. Ther. 242, 364.

Benveniste H. (1989) Brain microdialysis. J. Neurochem. 52, 1667.

Berger G., Mazière M., Knipper R., Prenant C. and Comar D. (1979) Automated synthesis of "C-labelled radiopharmaceuticals: imipramine, nicotine and methionine. Int. $J$. Appl. Radiat. Isot. 30, 393.

Clark J. C., Dowsett K., Horlock P. L. and Turton D. R. (1991) A readily adaptable process control system for carbon-11 methylations. Acta Radiologica. In press.

Cremer J. E. and Seville M. P. (1983) Regional brain blood flow, blood volume, and haematocrit values in the adult rat. J. Cereb. Bld Flow Metab. 3, 254.

Crouzel C., Langström B., Pike V. W. and Coenen H. H. (1987) Recommendations for a practical production of ["1'C]methyl iodide. Appl. Radiat. Isot. 38, 601.

Frost J. J. (1986) Imaging neuronal biochemistry by emission computed tomography: focus on neuroreceptors. TIPS 490.

Fuller R. W. (1987) Pharmacologic properties of serotonergic agents and antidepressant drugs. J. Clin. Psychiat. 48, (Suppl. 3) 5.

Hansch C. and Leo A. J. (1979) Substituent Constants for Correlation Analysis in Chemistry and Biology. Wiley, New York.

Hume S. P., Myers R., Manjil L. and Dolan R. (1989) Sertraline and paroxetine fail tests in vivo as 5 -HT reupake site ligands for PET. J. Cerebr Bld Flow Metab. 9, (Suppl. 1) 117.

Hyttel J. (1982) Citalopram-pharmacological profile of a specific serotonin uptake inhibitor with antidepressant activity. Prog. Neuro-Psychopharmacol. Biol. Psychiat. 6, 277.

Kalen P., Strecker R. E., Rosengren E. and Bjorklund A. (1988) Endogenous release of neuronal serotonin and 5-hydroxyindoleacetic acid in the caudate-putamen of the rat as revealed by intracerebral dialysis compared to high performance liquid chromatography with fluorimetric detection. J. Neurochem. 51, 122.

Kilbourn M. R., Haka M. S., Mulholland G. K., Jewett D. M. and Kuhl D. E. (1989) Synthesis of radiolabelled inhibitors of pre-synaptic monoamine uptake systems: [ $\left.{ }^{18} \mathrm{~F}\right]$ GBR 13119 (DA), [ $\left.{ }^{11} \mathrm{C}\right]$ nisoxetine (NE) and $\left[{ }^{11} \mathrm{C}\right]-$ fluoxetine (5-HT), J. Labelled Compd. Radiopharm 26, 412 .

Kragh-Sørensen P., Fredricson Overø K., Lindegaard Petersen O., Jensen K. and Parnas W. (1981) The kinetics of citalopram: single and multiple dose studies in man. Acta Pharmacol. Toxicol. 48, 53.

Langström B., Antoni G., Halldin C., Svard H. and Berson G. (1982) Synthesis of some ${ }^{11} \mathrm{C}$-labelled alkaloids. Chem. Scripta 20, 46.

Lasne M.-C., Pike V. W. and Turton D. R. (1989) The radiosynthesis of $\left[N\right.$-methyl- $\left.{ }^{\prime \prime} \mathrm{C}\right] \mathrm{ser}$ traline. Appl. Radiat. Isot. 40, 147.

Mazière M., Berger G. and Comar D. (1978) "CClomipramine: synthesis and analysis. $J$. Radioanalyt. Chem. 45, 453.

Overø K. F. (1978) Preliminary studies of the kinetics of citalopram in man. Eur. J. Clin. Pharmacol. 14, 69.

Palkovits M. and Brownstein M. J. (1988) Maps and Guide to Microdissection of the Rat Brain. Elsevier Science, New York.

Palkovits M., Raisman R., Briley M. and Langer S. Z. (1981) Regional distribution of ${ }^{3} \mathrm{H}$-imipramine binding in rat brain. Brain Res. 210, 493 ,

Paxinos G. and Watson C. (1986) The Rat Brain in Stereotaxic Coordinates. Academic Press, Orlando, Fla.

Phelps M. E., Hoffman E. J., Mullani N. A. and TerPogossian M. M. (1975) Application of annihilation coincidence detection to transaxial reconstruction tomography. J. Nucl. Med. 16, 210.

Plenge P., Mellerup E. T. and Laursen H. (1990) Regional distribution of the serotonin transport complex in human brain, identified with ${ }^{3} \mathrm{H}$-paroxetine, ${ }^{3} \mathrm{H}$-citalopram and ${ }^{3} \mathrm{H}$-imipramine. Prog. Neuro-Psychopharmacol. Biol. Psychiat. 14, 61.

Robb R. A. and Barillot C. (1988) Interactive 3-D image display and analysis. In Proc, SPIE Technical Symp. on Optics, Electro-optics and Sensors. Orlando, Fla.

Sanders-Bush E. and Steranka L. R. (1978) Immediate and long-term effects of $p$-chloroamphetamine on brain amines. Ann. N.Y. Acad. Sci. 305, 208.

Savaki H., Malgouris C., Bénavidès J., Laplace C., Uzan A., Guérémy C. and LeFur G. (1985) Quantitative autoradiography of $\left[{ }^{3} \mathrm{H}\right]$ indalpine binding sites in the rat brain: regional distribution. J. Neurochem. 45, 521 .

Sedvall G., Farde L., Persson A. and Wiesel F.-A. (1986) Imaging of neurotransmitter receptors in the living human brain. Arch. Gen. Psychiat. 43, 995.

Sharp T., Branwell S. R., Clark D. and Grahame-Smith D. G. (1989) In vivo measurement of extracellular 5hydroxytryptamine in hippocampus of the anaesthetised rat using microdialysis: changes in relation to 5-hydroxytryptaminergic neuronal activity. J. Neurochem. 53, 234.

Slopsema J. S., van der Gugten J. and de Bruin J. P. C. (1982) Regional concentrations of noradrenaline and dopamine in the frontal cortex of the rat: dopaminergic innervation of the prefrontal subareas and lateralisation of prefrontal dopamine. Brain Res. 250, 197.

Stahl M. S. and Palazidou L. (1986) The pharmacology of depression: studies of neurotransmitter receptors lead the search for biochemical lesions and new drug therapies. TIPS 349.

Ungerstedt U. and Hallstrom A. (1987) In vivo microdialysis-a new approach to the analysis of neurotransmitter in the brain. Life Sci. 41, 861 .

Wagner H. N. Jr (1986) Quantitative imaging of neuroreceptors in the living brain. Sem. Nucl. Med. 16, 51 .

Waynforth H. B. (1980) Experimental and Surgical Technique in the Rat. Academic Press, London.

Zaczek R. and Coyle J. T. (1982) Rapid and simple method for measuring biogenic amines and metabolites in brain homogenates by HPLC-electrochemical detection. $J$. Neurol. Trans. 53, 1. 